\title{
Neurosteroids and Seizure Activity
}

\author{
Barbara Miziak $^{1}$, Magdalena Chrościńska-Krawczyk ${ }^{2}$ and Stanisław J. Czuczwar ${ }^{1 *}$ \\ ${ }^{1}$ Department of Pathophysiology, Medical University of Lublin, Lublin, Poland, ${ }^{2}$ Department of Child Neurology, Medical \\ University of Lublin, Lublin, Poland
}

OPEN ACCESS

Edited by:

Takayoshi Ubuka,

Waseda University, Japan

Reviewed by:

Giovambattista De Sarro,

University of Catanzaro, Italy Ashish Dhir,

University of California, Davis,

United States

Giuseppe Biagini,

University of Modena and Reggio Emilia, Italy

*Correspondence:

Stanisław J. Czuczwar

czuczwarsj@yahoo.com

Specialty section:

This article was submitted to

Neuroendocrine Science,

a section of the journal

Frontiers in Endocrinology

Received: 16 March 2020 Accepted: 09 September 2020 Published: 30 September 2020

Citation:

Miziak B, Chrościńska-Krawczyk M and Czuczwar SJ (2020) Neurosteroids and Seizure Activity.

Front. Endocrinol. 11:541802. doi: 10.3389/fendo.2020.541802
Still circa $25 \%$ to $30 \%$ of patients with epilepsy cannot be efficiently controlled with available antiepileptic drugs so newer pharmacological treatment options have been continuously searched for. In this context, a group of endogenous or exogenous neurosteroids allosterically positively modulating GABA-A receptors may offer a promising approach. Among endogenous neurosteroids synthesized in the brain, allopregnanolone or allotetrahydrodeoxycorticosterone have been documented to exert anticonvulsant activity in a number of experimental models of seizures - pentylenetetrazol-, bicuculline- pilocarpine-, or $6 \mathrm{~Hz}$-induced convulsions in rodents. Neurosteroids can also inhibit fully kindled seizures and some of them have been reported to counteract maximal electroshock-induced convulsions. An exogenous neurosteroid, alphaxalone, significantly elevated the threshold for maximal electroconvulsions in mice but it did not potentiate the anticonvulsive action of a number of conventional antiepileptic drugs against maximal electroshock-induced seizures. Androsterone not only elevated the threshold but significantly enhanced the protective action of carbamazepine, gabapentin and phenobarbital against maximal electroshock in mice, as well. Ganaxolone (a 3betamethylated analog of allopregnanolone) needs special consideration for two reasons. First, it performed better than conventional antiepileptic drugs, diazepam or valproate, in suppressing convulsive and lethal effects of pentylenetetrazol in pentylenetetrazol-kindled mice. Second, ganaxolone has been evaluated in the randomized, double-blind, placebocontrolled phase 2 trial in patients with intractable partial seizures, taking maximally 3 antiepileptic drugs. The initial results indicate that add-on therapy with ganaxolone resulted in reduced seizure frequency with adverse effect being mainly mild to moderate. Possibly, ganaxolone may be also considered against catamenial seizures. Some positive effects of ganaxolone as an adjuvant were also observed in children with refractory seizures and its use may also prove efficient for the management of neonatal seizures associated with hypoxic injury. Neurosteroids positively modulating GABA-A receptor complex exert anticonvulsive activity in many experimental models of seizures. Their interactions with antiepileptic drugs seem ambiguous in mice. Initial clinical data indicate that ganaxolone may provide a better seizure control in patients with drug-resistant epilepsy.

Keywords: neurosteroids, ganaxolone, seizures, epilepsy, catamenial epilepsy 


\section{INTRODUCTION}

Epilepsy is a neurological disease which affects more than 70 million of the global population, $30 \%$ of whom are patients with refractory epilepsy (drug-resistant epilepsy) (1-3). Research conducted globally has invariably shown that, in terms of risk factors, epilepsy is hardly ever caused by a single determinant. A number of underlying causes are usually present, together with a genetic predisposition to the disease. Huge progress in terms of medical and pharmacological studies has facilitated the discovery of antiepileptic drugs (AEDs), which in one third of cases can suppress epileptic seizures, yet they do not affect in any way the root cause of the disease, so one cannot expect any improvements in the long-term prognosis of patients. Other solutions include surgical treatments, which might seem the most effective therapy. However, also in this case it has to be borne in mind that not every patient can undergo such a procedure $(1,4)$. In recent years other strategies in epilepsy treatment have emerged; however, there is still a great necessity for other options to be pursued, among which the most effective would be treatment impacting the etiopathogenesis of the disease, which would help to manage the condition, particularly in patients with refractory epilepsy $(1,2)$. Refractory seizures still affect about one third of patients with epilepsy in spite of a number of newer AEDs which appeared on the market over the last two decades (5). Consequently, there is a continuous search for more effective strategies and possibly neurosteroids could reduce the number of refractory epilepsy patients. When a newer or potential AED is evaluated, it is used in the form of an add-on therapy to the already existing antiepileptic treatment (6) and this is also the case with neurosteroids tried in patients with drug-resistant epilepsy (see below).

\section{METHODS}

Literature search for this review was generally based on English language articles with a few exceptions. PUBMED databases were the main source of relevant papers and the search areas included: neurosteroids, neurosteroids and seizure activity, neurosteroids and AEDs, neurosteroids and epilepsy. Some references of particular importance were searched for in the most relevant publications extracted from PUBMED.

\section{NEUROSTEROIDS}

Among the endogenous and exogenous steroid compounds, it is possible to distinguish neurosteroids-compounds possessing the ability to modulate neuronal activity and affect the physiology of the central nervous system (CNS). There is a distinction between steroid hormones which are secreted outside the nervous system (by endocrine glands) and neurosteroids (7). The term neurosteroids was introduced by Baulieu in 1981. This name is usually given to steroids which are synthesised de novo from cholesterol in the CNS, mainly by the glial cells and by neuronal mitochondria through pathways which are independent of the endocrine system. At first, only the elevation of dehydroepiandrosterone sulfate (DHEAS) was observed that was found in high concentrations in the brain long after gonadectomy and adrenalectomy. Only at a later stage did it occur that DHEAS could be also synthesised in the brain. Other neurosteroids were discovered with time, including androstenedione, pregnenolone (with their sulfates and lipid derivatives) as well as tetrahydrometabolites of progesterone and deoxycorticosterone (DOC) (7). There are two groups of neurosteroids-natural (endogenous-produced in the brain) and exogenous (Figure 1).

Mechanism of neurosteroid action is connected with allosteric regulation of gamma-aminobutyric acid (GABA)-A receptors, $N$-methyl-D-aspartate (NMDA) receptors, alpha1 glycine receptors, sigma receptors and voltage-dependent calcium channels (8-11). Neurosteroids potentiate synaptic GABA-A receptor function and also activate $\delta$-subunitcontaining extrasynaptic GABA-A receptors that mediate tonic currents and thus may play an important role in neuronal network excitability and seizure susceptibility (12).

Depending on their concentration, neurosteroids can directly activate receptors (in the case of high concentrations) or act as potent positive allosteric agonists (in the case of low concentrations) (12-15). In addition, these compounds can have a positive or a negative impact on the modulation of GABA-A receptor activity. The mechanism based on positive modulation was observed in the case of such neurosteroids as allopregnanolone (5alpha-pregnan3alpha-ol-20-one, ALLO), androsterone, progesterone, DOC, and tetrahydrodeoxy-corticosterone (THDOC). Through their binding to a specific place of the receptor, the above compounds bring about changes to its conformation, which results in the influx of $\mathrm{Cl}^{-}$ions into a neuron. Local hyperpolarization of the neuron which occurs in such situations leads to the inhibition of the cell's activity $(12,16)$. Neurosteroids in fact allosterically modulate synaptic and extrasynaptic GABA-A receptors, exhibiting a greater potency for the latter, containing delta subunits. Positive modulators, acting on extrasynaptic GABA-A receptors, located in the dentate gyrus of the hippocampus, may reduce seizure susceptibility (17). The second group includes compounds (pregnenolone sulfate and DHEAS), which suppress the GABAergic response through the mechanism of negative GABA-A receptor activity modulation. The above mechanism is based on the inhibition of chloride current, resulting in cell depolarization and activation (18). Further studies have shown that intracerebroventricular pregnenolone sulfate enhanced the convulsive activity of peripherally administered NMDA in mice and this effect was possibly dependent on the elevated concentration of hippocampal alanine, a precursor of glutamate and a probable co-agonist at the NMDA receptors (19).

The existing evidence also points to sigmal receptor as a possible target for neurosteroids. In fact, some neurosteroids were demonstrated to displace sigmal receptor radioligands in vivo and in vitro (20). Moreover, steroid sulfate esters (DHEAS or pregnenolone sulfate) differentially affected NMDA-induced noradrenaline release from preloaded hippocampal slices (DHEAS was an enhancer whilst pregnenolone sulfate-an 


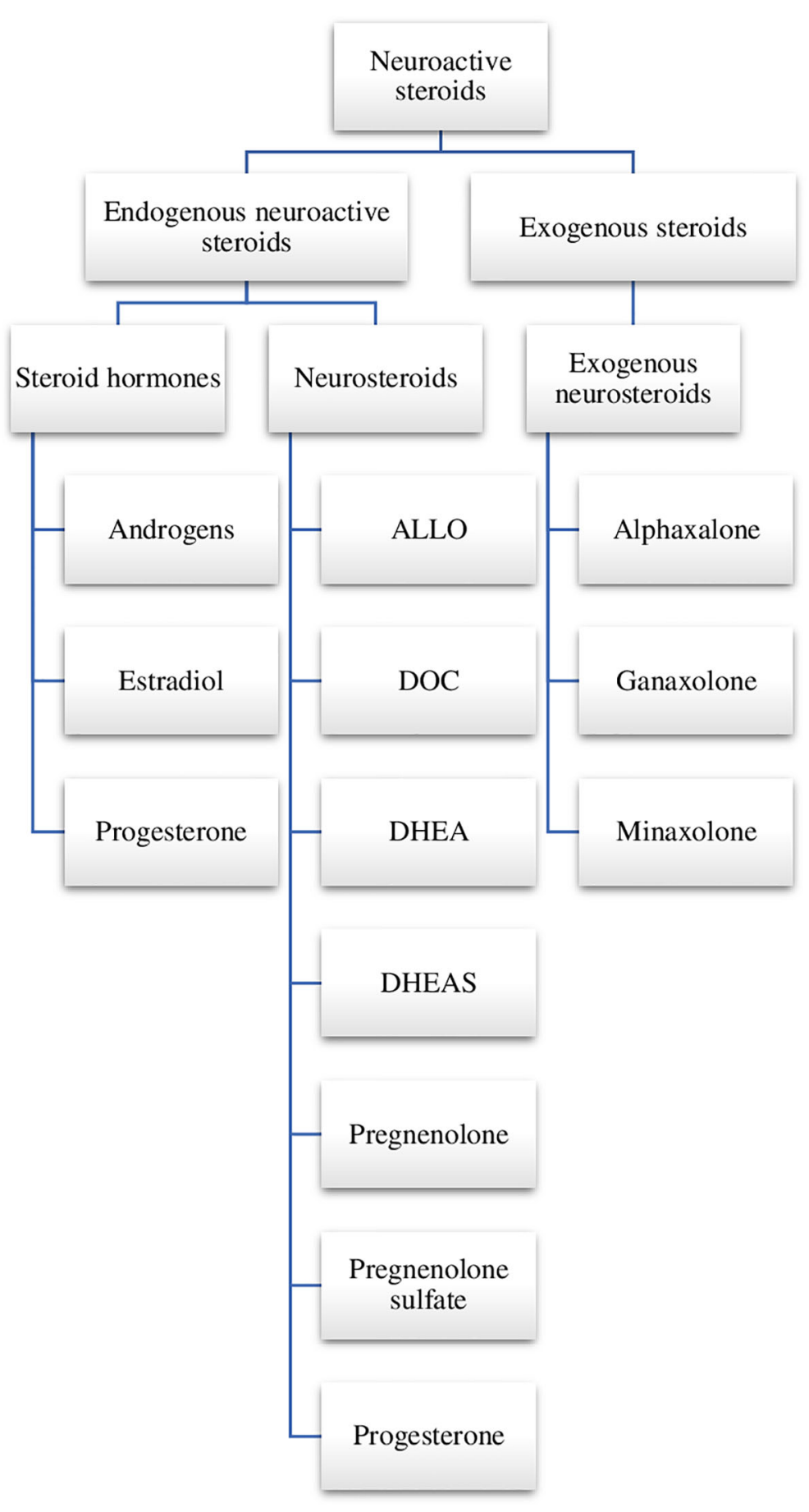

FIGURE 1 | Neuroactive steroids. ALLO, allopregnanolone; DOC, deoxycorticosterone; DHEA, dehydroepiandrosterone; DHEAS, dehydroepiandrosterone sulfate; SGE-516, 1-((3R,5R,8R,9R,10S,13S,14S,17S)-3-hydroxy-3,13-dimethylhexadecahydro-1H-cyclopenta[a]phenanthren-17-yl)-2-(2H-1,2,3-triazol-2-yl)ethan-1-one.

inhibitor). The inhibitory effect upon this parameter was shared by the high-affinity inverse sigma agonist and the sigma antagonist, haloperidol, attenuated the effect of steroid sulfate esters (21). The authors of this study conclude that DHEAS behaves as a sigma agonist whilst pregnenolone sulfate-as a sigma inverse agonist. Interestingly, progesterone behaved identically to haloperidol so it seems to be a sigma receptor antagonist (21).

Literature data draw attention to the effect of progesterone on calcium signaling-progesterone-calcium signaling hypothesis, 
which may explain therapeutic benefits of neurosteroids-a reduction of inflammation and edema, prevention of demyelination or inhibition of excitotoxic neuronal death. These detrimental effects are associated with significant elevations of the intracellular calcium concentration. Consequently, neuroprotection provided by progesterone seems dependent on the direct inhibition of voltage-gated calcium channels (22).

\section{NEUROSTEROIDS AND SEIZURE ACTIVITY}

\section{Progesterone and Its Metabolite}

There are studies which indicate that neurosteroids might also be important when it comes to the epileptogenesis described as the latent period. The latent period, which is a seizure-free period, has been defined as interval between the effect of the primary brain insult and the onset of the first spontaneous seizure. During this time, pathological changes occur in the brain, converting the normal brain into one that generates seizures (23).

In studies conducted on rats in the pilocarpine model of status epilepticus, it was found that during the latent period of epilepsy a higher expression of cytochrome P450 cholesterol side-chain cleavage (P450scc) enzyme was noted. This enzyme takes part in the brain synthesis of neurosteroids (24). Cholesterol is delivered by translocator protein (TSPO) into mitochondria in which P450scc is located (in the inner mitochondrial membrane). Next, cholesterol is cleaved to produce pregnenolone and is metabolized to tissue-specific steroids by enzymes, which operate in the endoplasmic reticulum $(24,25)$. Blocking neurosteroid synthesis by finasteride (a 5alpha-reductase and neurosteroid synthesis inhibitor) in rats after status epilepticus induced by pilocarpine, resulted in terminating the latent period and moreover, finasteride was evidently proconvulsant in rats with spontaneous seizure activity occurring after the latent period (24). Finasteride was also tested upon the anti-epileptogenic activity of progesterone in the mouse hippocampus kindling model of epileptogenesis (26). The neurosteroid synthesis inhibitor completely inhibited the progesterone anti-epileptogenic effect (reflected by the retardation of the kindled seizures) which could suggest that this particular action of progesterone may be dependent upon ALLO (26). Seyle et al. (27) were probably the first to conduct this type of study, in 1942, in which they evaluated the progesterone activity in pentylenetetrazol animal model, using immature male rats, demonstrating the hormone's anticonvulsant properties. In the subsequent years, other researchers also confirmed these results in studies conducted on both male and female rodents, using various progesterone doses and convulsive animal models, including the amygdala kindling model $(28,29)$, hippocampal kindling model (30), WAG/Rij rats, the genetic absence model (in this case, an increase in the number and duration of spike-wave discharges was demonstrated) (31) or kainate model (32). Billiar et al. (33), in turn, evaluated the distribution and metabolism of progesterone, the products of its metabolism, and estradiol, but this time they administered a constant infusion of [3H]- or [14C] progesterone and estradiol $[3 \mathrm{H}]$ to female rhesus monkeys. The experiments showed that the hormone levels were significantly higher in the cerebral tissues than in the carotid arterial blood, with the estradiol concentration being highest in the anterior pituitary (20 times). In the case of progesterone, its lowered concentrations were observed in the "central gray ( $P$ less than 0.05); the concentration levels were the same for the amygdala, hippocampus, preoptic-anterior hypothalamus, cerebellum, hypothalamus, thalamus, and anterior pituitary; and were higher in the cervical spinal cord, optic chiasm, mesencephalon, medulla oblongata, and pons" (33), when compared with the control group. Many years of research have shown that the administration of exogenous progesterone results in its cerebraltissue concentration's being tripled when compared to peripheral tissue levels. In the case of the administration of both progesterone and its metabolite-5alpha-pregnan-3,20-dione (5alpha-DHP) to rats (iv administration), it was demonstrated that the compounds accumulated in the brain with the highest concentration in the hypothalamus and anterior pituitary regions, but in the cerebral cortex the concentration was very low (34). Whilst its high concentration in the anterior pituitary and hypothalamus is associated with gonadotropin release (34), the progesterone metabolite may possess an anticonvulsive potential. Actually, intravenous 5alpha-DHP reduced generalized and focal seizures in female fully kindled rats (35) and this effect was related to its interaction with GABA-A receptors (36).

Akula et al. (37) compared the anticonvulsant effect of progesterone (at doses of $20-80 \mathrm{mg} / \mathrm{kg}$ s.c). and AEDs on the intravenous pentylenetetrazol-induced seizure threshold in mice. All the studied compounds proved to have anticonvulsant dosedependent effects. Moreover, it was shown that progesterone's effect was stronger than that of tiagabine, GABA, adenosine, gabapentin, but weaker than that of clonazepam, diazepam, chlordiazepoxide, phenobarbital, carbamazepine, pentobarbital, pregabalin, and phenytoin (37).

Clinical data indicate that status epilepticus may be associated with a profound reduction in cerebrospinal fluid concentration of progesterone which was even $64 \%$ lower than in matched controls (38).

\section{Allopregnanolone}

Among the known neurosteroids, ALLO is the potent and the most thoroughly examined natural endogenous positive GABAA receptor modulator (8). This compound is responsible for the maturing of the central nervous system, and a range of behaviour in adult life, which was proved by Mòdol et al. (39). It was found that ALLO stimulated myelinisation, synaptogenesis and displayed protective and trophic properties in relation to neurons, both during the development period and in the case of disorders (40-42). Extensive research has shown that disturbances in its levels play an important role in the pathomechanism of many diseases, including neurological and psychiatric disorders (43). By modulating the level of neurosteroids in rat neonates, it was revealed that ALLO 
modified exploratory and anxiety-like behaviour and disrupted aversive learning in the adult animals. (39).

Lévesque et al. (44) evaluated the effect of ALLO (at doses of 9.6-12.8 $\mathrm{mg} / \mathrm{kg} /$ day) on interictal jumps and high frequency oscillations (ripples: $80-200 \mathrm{~Hz}$, rapid ripples: $250-500 \mathrm{~Hz}$ ) in the pilocarpine model of mesial temporal lobe epilepsy. It was determined that the neurosteroid significantly decreased the frequency of interictal spikes and fast ripples in the hippocampal CA3 field when compared to the control group. Others showed the anticonvulsant activity of the neurosteroid which attenuated behavioral and electrographic seizures in a model of status epilepticus despite benzodiazepine resistance (45). Interestingly, hippocampal ALLO concentration was significantly lowered in rats surviving kainate-induced status epilepticus when measured 9 weeks after (46). Human data seem in line with the results observed in rodents. Meletti et al. $(38,47)$ analyzed ALLO concentrations in samples of cerebrospinal fluid of patients with status epilepticus. There was a significant around 30\% decrease in ALLO levels. In 2017, two cases of adults with super-refractory status epilepticus were reported, in whom the introduction of treatment with ALLO (at doses of $5.6 \mathrm{mg} / \mathrm{h}$ for 5 days in the form of $120 \mathrm{~h}$ continuous infusion) brought positive results (48).

\section{Deoxycorticosterone}

The next neurosteroid-DOC is a mineralocorticoid precursor whose anticonvulsant properties are connected with its enzymatic conversion to THDOC. The converted neurosteroid acts as a positive allosteric modulator of GABA-A receptors. It was found that DOC level can change under stress, because its synthesis is controlled by an adrenocorticotropic hormone. The above relationship can be explained by stress-dependent changes in the susceptibility to seizures, which are especially observed in children (49).

Anticonvulsant activity of DOC has been shown below (in the section devoted to the paediatric population). Interestingly, when evaluated in adult rats challenged with gamma-hydroxybutyric acid (a model of generalized absence seizures), THDOC potentiated seizure activity when given systemically or focally into thalamic ventrobasal nucleus (50).

\section{Pregnenolone Sulphate}

In the case of pregnenolone sulphate, the available results point to its proconvulsive activity. Maciejak et al. (19) revealed that an increase in the level of pregnenolone sulfate resulted in increased alanine concentration-a precursor of glutamate, which contributes to the development of seizures. A similar effect was obtained by Reddy and Kulkarni (18), who studied the impact of long-term pregnenolone sulphate and DHEAS (both at a dose of $10 \mathrm{mg} / \mathrm{kg} /$ day for 4 week) administration on convulsive activity in the mouse pentylenetetrazol model. A clear cut decrease in the seizure threshold was observed. In addition, the authors drew attention to the fact that the long-term administration of DHEAS resulting in the proconvulsive activity was prevented by longterm pretreatment with progesterone (at a dose of $5 \mathrm{mg} / \mathrm{kg}$ ) or ALLO (at a dose of $0.1 \mathrm{mg} / \mathrm{kg}$ ) (18).

\section{Ganaxolone}

Ganaxolone (3alpha-hydroxy-3beta-methyl-5alpha-pregnan-20one; GNX) belongs to exogenous neurosteroids, and is the 3betamethylated exogenous analogue of ALLO. GNX has a mechanism similar to its natural analogue, i.e. it is an allosteric modulator of GABA-A receptors (binds to both synaptic and extrasynaptic GABA-A receptors) (51, 52). In the case of the activation of synaptic GABA-A receptors, whereas the activation of extrasynaptic GABA-A receptors is connected with persistent or tonic inhibition (53). Additionally, it was confirmed that the neurosteroid did not activate classic nuclear progesterone receptors (54).

GNX displays anticonvulsive properties, which was found in many animal seizure models, including limbic seizures in the 6$\mathrm{Hz}$ model, clonic seizures induced by pentylenetetrazol and bicuculline or amygdala-kindled seizures (54). Gasior et al. (55) in their experiments compared the activity of GNX with diazepam and valproate, in which they showed that GNX (effective doses of GNX predicted to protect $50 \%$ of the mice in this model $\left[\mathrm{ED}_{50}\right]-3.45 \mathrm{mg} / \mathrm{kg}$ against the clonic phase), was the most effective anticonvulsant, because it decreased the convulsive activity (clonic and tonic seizures) and lethal effects of pentylenetetrazol. By comparison, diazepam displayed anticonvulsant activity involving tonic seizures and lethality, and valproate only suppressed the tonic attacks (55). These results were confirmed in behavioral and electrographic seizures in fully amygdala-kindled mice, representing a model of mesial temporal lobe epilepsy (56). Mares and Stehlíková (57) studied the activity of GNX (in 5-40 mg/kg doses) in another model-cortical epileptic afterdischarges. Rats $(12,18$, and 25day-old) were used for this study. The administration of GNX (at $40 \mathrm{mg} / \mathrm{kg}$ ) inhibited progressive prolongation of cortical epileptic afterdischarges in 25-day-old rats and postponed it in 12-day-old rats. In 18-day-old rats, no significant protective effects of the drug were observed (56). GNX was also evaluated in WAG/Rij rats, a genetic model of absence epilepsy, following intracerebral injections (57). When administered bilaterally into nucleus ventralis posteromedialis, nucleus reticularis thalami, nucleus ventralis posterolateralis (thalamic nuclei), the occurrence of epileptic spike-wave discharges was worsened. However, when microinjected into the peri-oral region of the primary somatosensory cortex, GNX (at doses of 100, 200, 400 pmol and $1 \mathrm{nmol} /$ side) suppressed spike-wave discharges. Practically, ALLO (at doses of 200, $400 \mathrm{pmol}$ and $1 \mathrm{nmol} / \mathrm{side}$ ) produced a very similar response. The effects of pregenenolone sulphate (at doses of $100,200,400 \mathrm{pmol}$ and $1 \mathrm{nmol} / \mathrm{side})$ were dosedependent-the drug was generally proconvulsant at low doses and anticonvulsant at higher doses when microinjected into thalamic nuclei or somatosensory cortex (58).

GNX (at a dose of $1500 \mathrm{mg} /$ day) has been also studied as an add-on therapy in randomized, placebo-controlled trials involving adult patients with partial onset epilepsy with or without secondary generalization. A Phase II trial was conducted in 147 refractory adults (100 females and 47 males in the age range of 18-69 years) (59). Out of 131 patients who completed the trial, 124 subjects were enrolled into the open- 
label extension study. The results of the trial were quite encouraging-GNX reduced by $18 \%$ mean weekly seizure frequency (vs a $2 \%$ enhancement in placebo group). Responder rates were evaluated as a percentage of patients in whom reduction of seizures reached at least $50 \%$. The rates were 26 and $13 \%$ in GNX and placebo groups, respectively. A possibility that the observed beneficial results in patients on GNX could be dependent on gender or concomitant medication was excluded. Remarkably, GNX positive efficacy seems to be long-term which can be inferred from the open-label extension (59). Because of the adverse effects (mainly dizziness, fatigue and somnolence), $7 \%$ of GNX and $6 \%$ of placebo subjects had to discontinue treatment. Thirty six patients in the open-label extension continued GNX treatment for a longer period than one year and the observed adverse effects did not differ from those reported in the Phase II trial (58). Some more results from the open-label extension were published in 2013 (60). Among adverse effects observed in more than $10 \%$ of patients, were: headache $(21 \%)$, convulsion (16\%), fatigue (16\%), fall (14\%), nasopharyngitis $(14 \%)$, dizziness $(13 \%)$, contusion $(12 \%)$, and nasal congestion (10\%) (60). Detailed analysis of the results was published in 2017 (61). The authors indicate that generally, the adverse effects in the GNX group were mild to moderate. Among the untoward events leading to discontinuation in patients receiving GNX were: headache, lethargy and in placebo group: postictal psychosis, headache and convulsion. Clinical laboratory tests revealed no major disturbances-only in one patient on GNX mild thrombocytopenia was found which, however, did not result in treatment discontinuation (61).

\section{Minaxolone and Alphaxalone}

Other exogenous neurosteroids include minaxolone $(2 \beta, 3 \alpha, 5 \alpha, 11 \alpha)$ 11-(dimethylamino)-2-(ethoxy-3-hydroxypregnan-20-one), and alphaxalone (5 $\alpha$-pregnan-3 $\alpha$-ol-11,20-dione) - compounds whose mechanisms of action are also based on positive interactions at the $\alpha 1$ glycine receptor. However, the respective EC50 values for minaxolone or alphaxalone were roughly 10 times higher compared to GABA-A receptors (62). Both minaxolone and alphaxalone proved to be effective anticonvulsant agents against pentylenetetrazol - and bicuculline-induced convulsions in rodents. In addition, moderate anticonvulsive activity was displayed by the latter in other models, including kindling and electroconvulsions in mice (63). Also, alphaxalone exerted distinct anticonvulsant effects against NMDA-induced convulsions in mice and reduced NMDAproduced mortality (64). This protective activity was shared by other positive modulators of GABA-A receptors-ALLO and androsterone. Interestingly, the ALLO precursor, $5 \alpha$-pregnane3,20-dione, was completely ineffective in this respect. However, this neurosteroid has nothing to do with GABA-A receptors (64). Another study, however, found alphaxalone ineffective against pentylenetetrazol-induced seizure activity in mice or amygdalakindled seizures in rats (65). Aminophylline-induced convulsions in mice were also not affected by the neurosteroid (65). Apart from the evaluation of the anticonvulsant activity of alphaxalone per se, this compound was also combined with a number of AEDs in the maximal electroshock (MES)- and pentylenetetrazol-induced convulsions in mice. First, alphaxalone (at $2.5 \mathrm{mg} / \mathrm{kg}$ ) was demonstrated to raise the threshold for electronvulsions but in this effective dose it surprisingly reduced the protective activity of valproate against MES and at 2.5-5 mg/ $\mathrm{kg}$, alphaxalone also negatively interacted with this AED in pentylenetetrazol-induced seizures. As regards other AEDs, the anticonvulsant activity of carbamazepine, phenobarbital, phenytoin and clonazepam was not modified by the neurosteroid against MES. Similarly, the protective action of clonazepam, ethosuximide and phenobarbital remained unchanged in the presence of alphaxalone. In aminophyllineinduced convulsions and amygdala-kindled seizures the protective activity of conventional AEDs (including valproate) was not affected by alphaxalone (65).

Alphaxalone was also tried in a rat model of generalized absence seizures produced by gamma-hydroxybutyric acid (50). Following its systemic or focal administration into thalamic ventrobasal nucleus, an exacerbation of seizures was noted. However, no effect was observed following its administration into thalamic reticular nucleus (50).

\section{Combination of Neurosteroids (Allopregnanolone and Ganaxolone) With Tiagabine or Midazolam}

The examined combination of neurosteroids included ALLO and GNX with the GABA-reuptake inhibitor tiagabine or the benzodiazepine derivative - midazolam against tonic inhibition in dentate gyrus granule cells (DGGCs) or in the hippocampal kindling and $6-\mathrm{Hz}$ seizure models (66). The authors provided evidence that combining individual neurosteroids with tiagabine in three standard proportions (1:1, 3:1 and 1:3) showed considerable synergism in their anticonvulsant action, and the pharmacological studies consistently pointed to the combinations' anticonvulsant effect. Similar results were obtained in the case of neurosteroids combined with midazolam. The combination of tiagabine with GNX at a 1:1 dose ratio exerted the strongest effect. As noted by the authors, the possible mechanism behind this action may result from both the effects on extrasynaptic GABA-A receptors and tiagabine -induced increase in synaptic GABA concentration. In turn, when considering the combination of the neurosteroid with midazolam, such positive effects may be possibly related to their actions at both synaptic and extrasynaptic GABA-A receptors (66). Apart from assessing pharmacokinetic parameters (see below), Zolkowska et al. (67) also evaluated the efficacy of intramuscular ALLO and GNX (each at a dose of $3 \mathrm{mg}$ / $\mathrm{kg}$ ) in the treatment of status epilepticus induced by tetramethylenedisulfotetramine in mice. The experiments showed that both neurosteroids were effective, however, ALLO displayed slightly greater effectiveness and speed of action, which was probably connected with its greater GABA-ergic potency (67).

There are data on the pharmacokinetic properties of ALLO and GNX (67). Plasma and brain levels of ALLO and GNX were determined in naïve mice at various time points following intramuscular dosing (in both cases at a dose of $3 \mathrm{mg} / \mathrm{kg}$ ). 
Maximum concentration values for ALLO and GNX (plasma Cmax) were 645 and $550 \mathrm{ng} / \mathrm{mL}$, respectively. Brain levels rose more slowly and peaked at $10 \mathrm{~min}$ in both cases, the respective Cmax values being $845 \mathrm{ng} / \mathrm{mL}$ for ALLO and $1239 \mathrm{ng} / \mathrm{mL}$ for GNX. On the basis of all pharmacokinetic parameters, it was found that the peak brain concentrations and brain exposure (AUC) for both steroids, was approximately 3-fold the plasma exposure (additionally, GNX was shown to be higher than ALLO). In the first case, the probable cause is the slightly higher hydrophobicity of GNX than ALLO ( $\log$ P values-5.423 and 5.042, respectively). In the second case, the authors indicate a higher lipophilicity of GNX as a probable cause (log P with 5.3 vs 4.9 for ALLO). Therefore, GNX initially concentrates in the brain to higher levels, being subsequently redistributed to fat tissue. Maintaining a more flatter distribution in the brain is another factor that may be responsible for the higher effectiveness of ALLO. The common feature of both neurosteroids is that both ALLO and GNX were highly bioavailable, indicating that they were almost completely absorbed following intramuscular injection (67).

\section{NEUROSTEROIDS AND CATAMENIAL EPILEPSY}

One of the possible causes of refractory epileptic seizures in women might be disturbances in the levels of progesterone and estrogen. These hormones may affect the electrical excitability of neurons and thus the seizure threshold. It was found that in the case of concentration fluctuations during the menstrual cycle, these hormones contributed to seizure exacerbation, called catamenial epilepsy. It is a dominant a type of drug-refractory epilepsy found in women of reproductive age. The fact that the characteristic feature of catamenial epilepsy is increased frequency of seizures at specific and repetitive times in the menstrual cycle serves as confirmation of how important a role is played here by the hormones $(68,69)$.

It was confirmed that the menstrual cycle had 3 sensitive periods in which increased seizure activity could be observed. Such increased activity usually occurs perimenstrually (C1 pattern), at ovulation (C2 pattern), and during the luteal phase (C3 pattern). The $\mathrm{C} 1$ and $\mathrm{C} 3$ phases see a drop in progesterone concentration, and the $\mathrm{C} 2$ period-a pre-ovulatory surge in estrogen. A decrease in progesterone concentration reduces sensitivity to the inhibitory neurotransmiter-GABA (70). It is suggested that the fluctuations in GABA-A receptor subtypes (especially in extrasynaptic $\delta$-GABA-A receptors) could be of importance as revealed in animal experiments $(71,72)$. It is suspected that the occurrence of this type of seizures in female patients is usually correlated with the discontinuation of neurosteroids, hence the idea to administer exogenous progesterone during the luteal phase, which is expected to eliminate the risk of a sudden drop in the hormone levels (68). However, the results of various research efforts, including randomised studies, appear to be discordant on that matter (70).

Progesterone is synthesised in the mitochondrial membranes of body cells, and in the cerebral tissue, in several stages, the first of which is homogenous, while the remaining stages can develop in various ways, which are different in the peripheral and central compartments. There is evidence that in the peripheral compartment, the 5 beta reduction pathway predominates, in turn in the central compartment-the 5 alpha pathway which is predominant in rats, monkeys, and humans (73).

At first it was believed that progesterone itself, in its basic form, possessed anticonvulsant properties, yet subsequent studies supported a notion that its anticonvulsant activity was most likely possible through its metabolism to other compounds. In addition, it is a known fact that progesterone and its secondary metabolites ALLO and 5alpha-DHP show anticonvulsant activity (73). Furthermore, this is supported by the fact that progesterone, through its neurosteroid derivative, ALLO, increases GABA-A receptor density in the brain, thus controlling possible seizures.

Animal studies were conducted in which the progesterone metabolism was blocked by finasteride which resulted in suppressing the anticonvulsant properties of this hormone (26).

It is very likely that the progesterone nuclear receptor does not participate in the anticonvulsant mechanism which is supported by double blind, placebo controlled and randomized studies by Dan-Haeri and Richens (74), conducted in a group of patients with catamenial exacerbation. The authors examined norethisterone-a compound which is similar to progesterone but has a stronger affinity to the progesterone nuclear receptor when compared to progesterone. However, these studies did not provide the primarily expected results, as it turned out that norethisterone did not possess anticonvulsant effects (74).

There is also a case of a woman with catamenial epilepsy, involving intractable complex partial and secondary generalized seizures and accompanying hormonal disorders, in whom seizure control could not be achieved, despite the administering of various AEDs, including barbiturates, carbamazepine, phenytoin and valproate. It was progesterone therapy which brought the expected therapeutic results, but only to the point at which the dermatologist ordered the treatment with finasteride (in view of the rapidly progressive male-pattern baldness). The additional therapy resulted in the recurrence of seizures, despite continued progesterone treatment, which again might suggest it is not the hormone which has anticonvulsant properties, but its metabolites are in fact anticonvulsant (75).

Herzog et al. $(76,77)$ conducted a randomized, double-blind, placebo-controlled, phase III, multicenter, NIH Progesterone Trial in which they examined the efficacy of adjunctive cyclic natural progesterone therapy in a group of almost 300 women who had been diagnosed with intractable partial seizures, with or without catamenial exacerbation. The patients in the study group were given progesterone at a dose of $200 \mathrm{mg} 3$ times a day for 12 months (from the $14^{\text {th }}$ to the $25^{\text {th }}$ day of each menstrual cycle). The dose was gradually reduced in the subsequent 3 days. The experiments showed that progesterone could be a very beneficial solution for women with perimenstrually exacerbated seizures; however, in the case of women with intractable partial epilepsy, cyclic progesterone is ineffective $(76,77)$.

A smaller study was conducted in 36 women with catamenial epilepsy-the patients experienced seizure activity throughout 
the second half of the menstrual cycle, accompanied by low serum concentrations of progesterone (78). Progesterone was administered at a daily dose of $50 \mathrm{mg}$ starting from the day $16^{\text {th }}$ and ending on day $25^{\text {th }}$ of each cycle. The results were encouraging. There was a $55.9 \%$ decline in the seizure frequency (primary and secondary generalized seizures) and a $63.1 \%$ decline in the partial seizure frequency-no improvement was evident in 5 patients (78).

The case is more difficult to prove with estrogen, because this hormone displays both pro- (79-81) and anticonvulsant properties (82), its mechanisms of actions being not fully understood. It is suspected that estrogen works through intracellular estrogen receptors, ER-alpha and ER-beta, which are found in nuclei of some neurons, e.g. in the hippocampus. Despite the fact that they are not very numerous when it comes to this structure, they seem to have a strong influence on the formation of synapses by neurons that do not have high levels of nuclear estrogen receptors. It was observed that non-nuclear estrogen receptors can occur outside of the cellular nuclei in dendrites, presynaptic terminals, and glial cells, where estrogen receptors can connect to second messenger systems to regulate various cellular events and signals to the nucleus through transcriptional regulators such as CREB (83). A different research group suggested that estradiol affected the hippocampal dendritic spine density through the activation of specific NMDA receptors (80). Smejkalova and Woolley (81), in turn, demonstrated that the hormone potentiated excitatory neurotransmission through a presynaptic mechanism via increased glutamate release. Studies are available in which the authors point to antiepileptic, and even neuroprotective, effects of estrogen. The hormone decreases neuronal death during seizures through up-regulation of the prosurvival molecule$\mathrm{Bcl}-2$, anti-oxidant potential as well as protection of NPY interneurons (82). In addition, it was demonstrated that the examined steroids caused "the induction of dendritic spine proliferation on serotonin neurons thus thawing a profound effect on serotonergic transmission" by the activation of 5-HT3 and 5-HT1A receptors (82).

It is possible that androgens also display a bimodal character. Animal studies have shown that testosterone can cause convulsive episodes to be aggravated, but, on the other hand, it was demonstrated to possess anticonvulsant properties which was connected with its transformation to various metabolites. The first case is a testosterone metabolism to $5 \alpha$-DHT by $5 \alpha$-reductase, which is then reduced by $3 \alpha$-hydroxysteroid oxidoreductase enzyme resulting in the synthesis of anticonvulsant metabolite $3 \alpha$-androstanediol, a potent GABA-A receptor modulating neurosteroid (84). In the second case, reduction of testosterone by aromatase generates proconvulsant $17-\beta$ estradiol $(84,85)$. Tutka et al. (86), in their experiments, assessed the effects of androsterone on the anticonvulsant properties of AEDs against MES-induced convulsions in mice. It was shown that androsterone, when administered alone $(80 \mathrm{mg} / \mathrm{kg})$, elevated the seizure threshold. This was not observed at lower doses $(5-40 \mathrm{mg} / \mathrm{kg})$. When combined with AEDs, androsterone (at $40 \mathrm{mg} / \mathrm{kg}$ ) significantly enhanced the anticonvulsant activity of phenobarbital, gabapentin and carbamazepine, but it did not affect the protective activity of phenytoin, lamotrigine, oxcarbazepine, topiramate, or valproate. The observed lack of androsterone's effect on the brain total concentration of AEDs suggests that the positive effect of this neurosteroid was not connected with pharmacokinetic interactions (86). Effects of neurosteroids on seizure susceptibility have been summarized in Table 1.

\section{NEUROSTEROIDS AND SEIZURE ACTIVITY IN THE PEDIATRIC POPULATION (HUMAN AND ANIMAL DATA)}

Epilepsy in children is a crucial problem, because its prevalence is greater than epilepsy in the adult population. This is associated with the increased susceptibility of immature cerebral tissue to spontaneous neuronal discharges. Due to the high risk of irreversible pathological changes, it is recommended to commence treatment as soon as possible. In addition, it has been shown that not only is an early start important, but also the appropriate type of treatment administered. The authors have proved that the introduction of the wrong AED therapy in the first line of treatment has long-term effects, including the reduction of the effectiveness of subsequent treatment courses with the appropriately selected AEDs (89). The treatment of neonates has proved to be extremely challenging, because epileptic seizures occurring in this group of patients are usually refractory to standard pharmacological treatment. There are cases in which AED administration can even aggravate the seizures (90). Consequently, there is a huge need to introduce new therapies which can be used in the youngest epilepsy patients.

Although ALLO possesses anticonvulsant properties, it is uncertain what effects it would display in children with epilepsy. With paediatric patients it should be borne in mind that GABA may become a depolarizing neurotransmitter in the brain, and GABAergic inhibition can be a result of both membrane hyperpolarization and a stimulus. In such a case GABA can act as both a stimulatory and an inhibitory neurotransmitter in an immature brain $(91,92)$.

The stimulating nature of GABAergic neurotransmission in the neonatal period can stem from, on the one hand, an increase in the level of $\mathrm{Na}^{+}-\mathrm{K}^{+}-2 \mathrm{Cl}^{-}$co-transporter (importing $\mathrm{Cl}^{-}$inside the cell- $\mathrm{NKCC} 1$ ), and, on the other, a decrease in the level of $\mathrm{K}^{+}-\mathrm{Cl}^{-}$co-transporter 2 (mediating $\mathrm{Cl}^{-}$transport out of the cell, KCC2). As a result, a high level of chloride ions is noted inside a cell (93). The researchers are of opinion that the activity of NKCC1 was high in the hippocampal and cortical neurons, especially in the first week of life, in both rats and humans, and it gradually decreased with time which was particularly apparent from the 14 th day of life $(94,95)$. It is believed that this is connected with the depolarizing to hyperpolarizing shift of GABA receptors, which starts around the 8-10th day of life and ends on the 14th day. This was proven in experiments on rat 
TABLE 1 | Neurosteroids - mechanisms of action and effects on seizure activity.

\begin{tabular}{|c|c|c|c|c|c|}
\hline & Neurosteroid & Mechanism of neurosteroid action & $\begin{array}{l}\text { Anticonvulsant } \\
\text { action }\end{array}$ & $\begin{array}{l}\text { Proconvulsant } \\
\text { action }\end{array}$ & Experiments on animal models \\
\hline \multirow[t]{7}{*}{$\begin{array}{l}\text { Endogenous } \\
\text { neurosteroids }\end{array}$} & Allopregnanolone & $\begin{array}{l}\text { positive allosteric modulator of GABA-A } \\
\text { receptors (38) }\end{array}$ & + & - & $\begin{array}{l}\text { Kainite, PTZ, } \\
\text { 4-aminopyridine model (13) }\end{array}$ \\
\hline & Androsterone & $\begin{array}{l}\text { positive allosteric modulator of GABA-A } \\
\text { receptors }\end{array}$ & + & - & MES model (86) \\
\hline & Deoxycorticosterone & $\begin{array}{l}\text { positive allosteric modulator of GABA-A } \\
\text { receptors (46) }\end{array}$ & + & - & $\begin{array}{l}\text { MES and PTZ model in juvenile rats ( } 87 \text {, } \\
88)\end{array}$ \\
\hline & & & - & + & $\begin{array}{l}\text { Model of generalized absence seizures in } \\
\text { rats (50) }\end{array}$ \\
\hline & $\begin{array}{l}\text { Dehydroepiandrosterone } \\
\text { sulfate }\end{array}$ & $\begin{array}{l}\text { negative modulator of GABA-A } \\
\text { receptors (18) } \\
\text { modulates the NMDA receptor (19) }\end{array}$ & - & + & PTZ model (18) \\
\hline & Pregnenolone sulfate & $\begin{array}{l}\text { negative modulator of GABA-A } \\
\text { receptors (18) } \\
\text { modulates the NMDA receptor (19) }\end{array}$ & - & + & $\begin{array}{l}\text { seizures induced by picrotoxin, } \\
\text { bicuculline and NMDA (19) }\end{array}$ \\
\hline & Progesterone & $\begin{array}{l}\text { positive allosteric modulator of GABA-A } \\
\text { receptors (59) }\end{array}$ & + & - & $\begin{array}{l}\text { Amygdala kindling model in rats }(19,29) \text {, } \\
\text { hippocampal kindling model }(30) \text {, } \\
\text { WAG/Rij rats, the genetic absence } \\
\text { model }(31) \\
\text { kainate model in rats (32) }\end{array}$ \\
\hline \multirow[t]{4}{*}{$\begin{array}{l}\text { Exogenous } \\
\text { neurosteroids }\end{array}$} & Alphaxalone & $\begin{array}{l}\text { positive allosteric modulator of GABA-A } \\
\text { and } \alpha 1 \text { glycine receptor (59) }\end{array}$ & + & - & $\begin{array}{l}\text { PTZ- and bicuculline-induced convulsion } \\
\text { (63) }\end{array}$ \\
\hline & & & - & + & $\begin{array}{l}\text { Model of generalized absence seizures in } \\
\text { rats }(50)\end{array}$ \\
\hline & Ganaxolone & $\begin{array}{l}\text { positive allosteric modulator of GABA-A } \\
\text { receptors }(47,48)\end{array}$ & + & - & $\begin{array}{l}6 \mathrm{~Hz} \text { model, PTZ, bicuculline seizures, } \\
\text { amygdala-kindled seizures }(54,55) \text {. } \\
\text { cortical epileptic afterdischarges in rats } \\
(57)\end{array}$ \\
\hline & Minaxolone & $\begin{array}{l}\text { positive allosteric modulator of GABA-A, } \\
\alpha 1 \text { glycine receptor (59) }\end{array}$ & + & - & $\begin{array}{l}\text { PTZ- and bicuculline-induced } \\
\text { convulsions (62) }\end{array}$ \\
\hline
\end{tabular}

Experiments were carried out in mice unless stated otherwise. MES, maximal electroshock; NMDA, N-methyl-D-aspartate; PTZ, pentylenetetrazol; +, present; -, absent.

CA3 hippocampal pyramidal cells $(94,96)$. Kolbaev et al. (97) in their in vivo studies on the CA3 region of hippocampal slices from immature (postnatal day 4-7) rats, showed that synaptic GABAergic neurotransmission suppressed epileptic discharges, and, in turn, strengthened extrasynaptic GABAergic drive caused epileptiform activity. It is also important to note that $\delta$-subunit expressing GABA-A receptors which participates in extrasynaptic GABAergic transmission, can be a potential target of neurosteroids, which was confirmed in a mouse model (98). Therefore, it is important to study the effects of ALLO on neuronal excitability in an immature brain. There are studies which show the anticonvulsant effect of ALLO in an immature brain. Sharopov et al. (99) examined the impact of ALLO on epileptiform activity in an in-toto hippocampus preparation of early postnatal mice (postnatal days 4-7). It was found that the neurosteroid, through a positive modulation of GABA-A receptors, did not show any impact on ictal-like epileptiform activity, however, an increase in interictal epileptiform events was observed. Additionally, based on studies using a patch-clamp, it was determined that ALLO prolonged the decay of GABAergic postsynaptic currents, but did not result in changes in the case of tonic GABAergic currents, which could result in an increase in the neuronal excitability of an immature brain (99). On the other hand, in the case of in vivo studies, results by Dhir and Chopra (13) should be taken into consideration. They examined the effects of a ALLO in 9-day-old rat neonates against seizures induced by kainic acid, pentylenetetrazol or 4-aminopyridine. Treatment with ALLO ( 5 and $10 \mathrm{mg} / \mathrm{kg}$ ) delayed the occurrence of status epilepticus, but did not impact on the myoclonic jerks or the mortality rate in the kainic acid group. In the case of convulsions evoked by 4aminopyridine, neurosteroid treatment-only at a higher dose of $10 \mathrm{mg} / \mathrm{kg}$ - contributed only to a delay in seizure activity. ALLO treatment (at $5 \mathrm{mg} / \mathrm{kg}$ ) in the pentylenetetrazol group, resulted in the protection of rat neonates against seizures and death (13). Another research group evaluated the impact of neurosteroids (ALLO-at doses of 20,30 and $40 \mathrm{mg} / \mathrm{kg}$, pregnanolone and triethylammonium 3alpha-hydroxy-20-oxo-5alpha-pregnan-21yl hydrogensuccinate (THDOC-conjugate-at 20 and $40 \mathrm{mg} / \mathrm{kg}$ ) on rat neonates in 3 age groups: 12-, 18- and 25-day-old rats (in the case of ALLO treatment) and in two age groups: 12- and 25day-old rats (in the case of other neurosteroids). Convulsions were induced through electrical stimulation using intracerebral electrodes. The experiments showed that all neurosteroids displayed anticonvulsant properties (the strongest effect was observed with pregnanolone) in 12-day-old rats, but only a tendency in 25-day-old ones. In turn, in the case of ALLO, no such tendency was observed in 18-day-old rats (100). Subsequent studies also assessed the effects of ALLO (at doses of 5-40 mg/ $\mathrm{kg}$ ) on convulsive activity in the pentylenetetrazol model, but this 
time the treatment involved 7-, 12-, 18-, 25- or 90-day-old rats (100). Similarly to the previous experiments, the neurosteroid supressed generalized tonic-clonic and minimal clonic seizures, in particular in the 12-day-old rat study group. The weakest anticonvulsant effect was, in turn, observed in the 90-day-old rat study group. The above results can be explained by the fact that the effects of ALLO lasted longer in young, than in adult rats (101). Other studies, also conducted by the same research team, evaluated the anticonvulsant properties of an analogue of ALLO -3alpha-hydroxy-21xi,22-oxido-21-homo-5alpha-pregnan-20on (at $40 \mathrm{mg} / \mathrm{kg}$ ) and GNX (at $60 \mathrm{mg} / \mathrm{kg}$ ) in a group of 12- and 25-day-old rat neonates against pentylenetetrazol-induced convulsions. A similar activity by both neurosteroids was found, but a more-favourable result was observed in younger rats (102). Based on the above studies it can be concluded that neurosteroids are the most effective when used in 12-day-old rat neonates, which the authors explain by the increased sensitivity towards the anticonvulsant potential of neurosteroids in younger rats (100). It is worth noting that, despite the positive effects of neurosteroids in rat neonates, one-week-old animals were excluded from the above studies while their brains roughly resemble those of pre-term children (103). In the case of preterms, it is worth stressing that they are particularly prone to CNS disorders. The high concentration of neurosteroids in advanced pregnancy protects the fetal brain against hypoxia and supports the normal development of CNS. When the ALLO level decreases, it brings about overexcitability in the neurons and increases the risk of brain damage secondary to hypoxia. Following birth (both normal and preterm) the neurosteroid level is found to be lower, which is particularly unfavourable for a preterm (104).

Age-dependent effect was also evident for DOC which exhibited clear cut anticonvulsant effects in neonatal, infant, weanling and juvenile rats against PTZ-induced convulsions (87). DOC at low dose $(10 \mathrm{mg} / \mathrm{kg})$ lost its protective effect and its anticonvulsant activity after a high sedating dose $(40 \mathrm{mg} / \mathrm{kg})$ was significantly reduced after puberty (87). Further experiments provided evidence that this neurosteroid was effective against MES (87, 88) and hippocampal kindling in 15-day-old rats, too. Much higher doses of DOC were required for adult rodents (88). Interestingly, the anticonvulsant efficacy of DOC against PTZ was significantly reduced by finasteride, indicating that the neurosteroid acts via its metabolites, dehydrodeoxycorticosterone and THDOC (105). Actually, these metabolites were found effective against PTZinduced convulsions in infant (15-day-old) rats (105).

Kaciński et al. (43) assessed the effects of ALLO on pseudoseizures in children. The children were divided into 3 groups: (I) children with pseudoseizures without treatment with AEDs; (II) children with pseudoseizures and treated with AEDs; (III) children without pseudoseizure attacks and no treatment with AEDs. The results showed no significant changes in ALLO levels, both before and after provoking pseudoseizures by placebo. It might point to the fact that during pseudoseizure attacks, in contrast to epileptic seizures, endogenous anticonvulsant and anxiolytic neurosteroid levels do not increase. In addition, the authors noted that the low ALLO level can intensify the stress response and contribute to the occurrence of pseudoseizures (43). Broomall et al. (106) were the first to describe two children with super-refractory status epilepticus. This disorder is characterized by resistance to benzodiazepine and barbiturate treatment, which is most probably connected to the internalization of synaptic GABA-A receptors. ALLO was used, and it made it possible to discontinue general anesthetic infusions (106). In their studies, Grosso et al. (107), suggest that circulating ALLO significantly increases in the post-ictal phase. They found no significant differences in the post ictal serum ALLO between patients with partial seizures and those with generalized seizures. They included three groups of subjects in the study. Group 1 consisted of 18 children affected by complex partial seizures. Group 2 consisted of 11 children presenting with generalized epilepsy. Group 3 consisted of 20 healthy age-matched subjects. Serum ALLO levels were assayed in the inter-ictal phase and within $30 \mathrm{~min}$ after an epileptic event (107). A possibility exists that a reduced blood ALLO concentration may be causally related to pathophysiology of protocadherin 19 female limited epilepsy (PCDH19-FE) which is actually a clear cut infantile onset syndrome with autism and intellectual disability in some cases. Genes, encoding enzymes involved in the metabolism of steroid hormones, were evaluated in transcriptomes of primary skin fibroblasts. Out of the AKR1C1-3 genes, significant changes were found in AKR1C3 in terms of reduced mRNA and protein concentrations in PCDH19-FE patients (108). Obviously, the reduced blood concentration of ALLO followed in these patients which could be responsible for the development of PCDH19-FE (108). Further studies on PCDH19-FE patients confirmed the earlier findings of Tan et al. (108), showing that the serum concentration of ALLO was significantly reduced not only in baseline but after stimulation with ACTH as well (109). Strikingly, the synthesis of pregnenolone sulphate was even more reduced than that of ALLO so a hypothesis that seizures could be generated by an assumed imbalance in the ALLO/pregnenolone sulphate ratio proved unlikely (109).

One of the first studies to evaluate the effect of GNX on convulsive activity in the paediatric population was conducted approximately 20 years ago. Kerrigan et al. (110) examined this neurosteroid in the population of children with refractory infantile spasms, or with continuing seizures following a prior history of infantile spasms (aged 7 months to 7 years). It was determined that GNX reduced the number and frequency of seizures from $25 \%$ to $>50 \%$. In turn, Pieribone et al. (111) evaluated the anticonvulsive effects of GNX in children (aged 5-15) with highly refractory focal and generalized crypto-symptomatic epilepsy. The results confirmed that the neurosteroid produced anticonvulsive effects. In some patients, adverse events were observed; however, all of them were described as mild to moderate. Yawno et al. (112) suggested that GNX should also be administered in the case of convulsions in neonates and preterms. The author draws attention to the fact that the drug, on one hand, is very safe, because most probably it produces no negative effects on the neonates' brains, and, on the other, it can prevent or considerably reduce the prevalence of permanent damage resulting from hypoxia, preterm birth, or epilepsy (112). Clinical research has been presented in Table 2. 
TABLE 2 | Neurosteroids-clinical research.

\begin{tabular}{|c|c|c|c|c|}
\hline Neurosteroids & Type of seizures & Trial group & Doses applied & References \\
\hline \multirow[t]{3}{*}{ Allopregnanolone } & generalized convulsions and myoclonus & Adults & $\begin{array}{l}670.8 \mathrm{mg} \text { ( } 5.6 \mathrm{mg} / \mathrm{h} \text { for } 5 \text { days), intravenous solution, } \\
\text { containing } 6 \% \text { hydroxypropyl- } \beta \text {-cyclodextrin in } 0.9 \% \text { sodium } \\
\text { chloride injection }\end{array}$ & $(48)$ \\
\hline & super-refractory status epilepticus & Children & $\begin{array}{l}\text { iv solution }(0.5 \mathrm{mg} / \mathrm{ml} \text { in } 0.9 \% \mathrm{NaCl} \text { with } 6 \% \text { Captisol for } 5 \\
\text { days }\end{array}$ & $(106)$ \\
\hline & $\begin{array}{l}\text { complex partial seizures } \\
\text { generalized epilepsy }\end{array}$ & $\begin{array}{l}\text { Children (aged } 11 \\
\text { months to } 7.8 \text { years) }\end{array}$ & no data & $(107)$ \\
\hline \multirow[t]{3}{*}{ Progesterone } & catamenial epilepsy & Adults (women) & $\begin{array}{l}200 \text { mg three times daily on days } 14-25 \text {, followed by a 3-day } \\
\text { taper) of each cycle }\end{array}$ & $(75)$ \\
\hline & $\begin{array}{l}\text { intractable partial seizures, with or without } \\
\text { catamenial exacerbation. }\end{array}$ & Adults (women) & $\begin{array}{l}200 \mathrm{mg} 3 \text { times a day for } 12 \text { months (from the 14th to the } \\
\text { 25th day of each menstrual cycle) }\end{array}$ & $(76,79)$ \\
\hline & catamenial epilepsy & Adults (women) & $\begin{array}{l}50 \text { mg starting from the day } 16 \text { th and ending on day } 25 \text { th of } \\
\text { each cycle. }\end{array}$ & $(78)$ \\
\hline \multirow[t]{3}{*}{ Ganaxolone } & $\begin{array}{l}\text { partial onset epilepsy with or without } \\
\text { secondary generalization }\end{array}$ & $\begin{array}{l}\text { Adults (aged 18-69 } \\
\text { years) }\end{array}$ & $1,500 \mathrm{mg} /$ day & $(59)$ \\
\hline & $\begin{array}{l}\text { refractory infantile spasms, or with } \\
\text { continuing seizures following a prior history } \\
\text { of infantile spasms }\end{array}$ & $\begin{array}{l}\text { Children (aged } 7 \\
\text { months to } 7 \text { years). }\end{array}$ & $\begin{array}{l}\text { the dose of ganaxolone was progressively increased to } 36 \\
\mathrm{mg} / \mathrm{kg} / \mathrm{d} \text { (or to the maximum tolerable dose) over a period of } \\
4 \text { weeks and then maintained for } 8 \text { weeks prior to tapering } \\
\text { and discontinuation of the attack }\end{array}$ & (110) \\
\hline & $\begin{array}{l}\text { highly refractory focal and generalized } \\
\text { crypto-symptomatic epilepsy }\end{array}$ & $\begin{array}{l}\text { Children (aged } 5-15 \\
\text { years) }\end{array}$ & $\begin{array}{l}\text { ganaxolone in a } 1: 1 \text { complex with } \beta \text {-cyclodextrin in a dose } \\
\text { escalation ( } 1 \mathrm{mg} / \mathrm{kg} \text {, b.i.d. to } 12 \mathrm{mg} / \mathrm{kg} \text { t.i.d.) schedule over } \\
16 \text { days }\end{array}$ & $(111)$ \\
\hline
\end{tabular}

\section{CONCLUSIONS}

It is evident that endogenous and exogenous neurosteroids may exert anti- or proconvulsant activity. As already indicated above, the anticonvulsant activity is associated with the positive modulation of GABA-A receptors and by the way, some anticonvulsant neurosteroids were documented to inhibit aspartate release from rat hippocampal slices (64). The anticonvulsant neurosteroids comprise for instance: androsterone, progesterone, ALLO, alphaxalone, GNX. In contrast, proconvulsant neurosteroids (pregnenolone sulfate or DHEAS) negatively modulate the function of GABA-A receptor complex. Modulation of seizure activity may be also associated with sigma receptors as a sigma receptor antagonist, rimcazole, lowered the convulsive threshold on one hand, but on the other, it potentiated the anticonvulsive activity of phenobarbital and valproate against MES in mice (113). When considering anticonvulsant effects of neurosteroids, progesterone block of voltage-operated calcium channels may be of importance as many agents expressing this mechanism of action express anticonvulsant activity (114). Modulation of seizures via glycine 1 receptors seems rather unlikely in vivo due to the relatively weak binding of neurosteroids to these receptors. A completely different situation may be encountered in absence seizures as revealed from WAG/Rij rats. The observed worsening of absence seizures in 6month-old WAG/Rij rats may be associated with the upregulation of thalamic $\alpha-4$ and $\delta$ GABA-A receptor subunits which probably leads to an enhanced GABA-ergic inhibition of thalamic relay neurons (115).

Because intractable seizures generally require adjuvant treatments, interactions of neurosteroids with AEDs are of particular importance. Preclinical data point to the beneficial effects of androsterone when combined with carbamazepine, gabapentin and phenobarbital (86). Also, combinations of ALLO and GNX with tiagabine or midazolam were found highly effective against hippocampal kindling and $6 \mathrm{~Hz}$ induced convulsions in mice (66). The results concerning alphaxalone are not that encouraging as this neurosteroid diminished the anticonvulsant activity of valproate against MES or pentylenetetrazol in mice. Unexpectedly, the total brain concentration of valproate was elevated by alphaxalone (65).

Clinical data are generally positive, pointing to progesterone as an effective drug against catamenial epilepsy (76-78). Nevertheless, the hormone is ineffective as regards intractable partial seizures in women (76). A very promising AED, GNX, has entered phase III study (116). It has shown a considerable efficacy as an adjuvant against infantile spasms (110), highly refractory epilepsy in children (111) and possibly ganaxolone will prove effective for the management of neonatal seizures following hypoxic injury (112). Positive results are also available from a trial conducted on adult patients with partial epilepsy (59-61).

Using neurosteroids in the paediatric population deserves special attention, especially in the period of the last semester of gestation up till the first several years after birth. This is actually the period of the intensive synaptogenesis (117). Experimental data obtained from immature animals clearly indicate the drugs enhancing GABA-mediated inhibition can induce massive neuronal apoptosis similarly to alcohol which is known to cause fetal alcohol syndrome (117). Whether neurosteroids via GABA-mediated events may cause remote clinical problems in the paediatric population due to the enhanced apoptosis is at present not known. 


\section{AUTHOR CONTRIBUTIONS}

$\mathrm{BM}$ was involved in writing most parts of the first draft and designing the table and schemes. MC-K dealt with some aspects of the treatment of pediatric patients with neurosteroids. SC prepared conclusions and critically read the whole manuscript, performing necessary additions (with relevant references) and revisions.

\section{REFERENCES}

1. Thijs RD, Surges R, O’Brien TJ, Sander JW. Epilepsy in adults. Lancet (2019) 16:393(10172):689-701. doi: 10.1016/S0140-6736(18)32596-0

2. Amin U, Benbadis SR. Avoiding complacency when treating uncontrolled seizures: why and how? Expert Rev Neurother (2020) 15:1-9. doi: 10.1080/ 14737175.2020.1713100

3. Chouchi M, Klaa H, Ben-Youssef Turki I, Hila L. ABCB1 Polymorphisms and drug-resistant epilepsy in a Tunisian population. Dis Markers (2019) 2019:1343650. doi: 10.1155/2019/1343650

4. Ma BB, Fields MC, Knowlton RC, Chang EF, Szaflarski JP, Marcuse LV, et al. Responsive neurostimulation for regional neocortical epilepsy. Epilepsia (2020) 61(1):96-106. doi: 10.1111/epi.16409

5. Łukawski K, Gryta P, Łuszczki J, Czuczwar SJ. Exploring the latest avenues for antiepileptic drug discovery and development. Expert Opin Drug Discovery (2016) 11(4):369-82. doi: 10.1517/17460441.2016.1154840

6. Błaszczyk B, Miziak B, Czuczwar P, Wierzchowska-Cioch E, Pluta R, Czuczwar SJ. A viewpoint on rational and irrational fixed-drug combinations. Expert Rev Clin Pharmacol (2018) 11(8):761-71. doi: 10.1080/17512433.2018.1500895

7. Dubrovsky BO. Steroids, neuroactive steroids and neurosteroids in psychopathology. Prog Neuropsychopharmacol Biol Psychiatry (2005) 29 (2):169-92. doi: 10.1016/j.pnpbp.2004.11.001

8. Basta-Kaim A, Leskiewicz M, Budziszewska B, Lason W. The role of neurosteroids in the central nervous system function. [Article in Polish]. Przegl Lek (2005) 62:1287-92.

9. Compagnone NA, Mellon SH. Neurosteroids: biosynthesis and function of these novel neuromodulators. Front Neuroendocrinol (2000) 21:1-56. doi: 10.1006/frne.1999.0188

10. Leśkiewicz M, Budziszewska B, Basta-Kaim A, Zając A, Kacinski M, Lason W. Effects of neurosteroids on neuronal survival: molecular basis and clinical perspectives. Acta Neurobiol Exp (Wars) (2006) 66:359-67.

11. Borowicz KK, Czuczwar SJ. [Perspectives of neurosteroid derivative application in antiepileptic therapy]. [Article in Polish]. Przegl Lek (2005) 62(11):1293-5.

12. Reddy DS. Role of hormones and neurosteroids in epileptogenesis. Front Cell Neurosci (2013) 7:115:115. doi: 10.3389/fncel.2013.00115

13. Dhir A, Chopra K. On the anticonvulsant effect of allopregnanolone (a neurosteroid) in neonatal rats. Life Sci (2015) 143:202-8. doi: 10.1016/ j.lfs.2015.09.008

14. Amengual-Gual M, Sánchez Fernández I, Wainwright MS. Novel drugs and early polypharmacotherapy in status epilepticus. Seizure (2019) 68:79-88. doi: 10.1016/j.seizure.2018.08.004

15. Ratner MH, Kumaresan V, Farb DH. Neurosteroid actions in memory and neurologic/neuropsychiatric disorders. Front Endocrinol (Lausanne) (2019) 10:169:169. doi: 10.3389/fendo.2019.00169

16. Gibbs TT, Russek SJ, Farb DH. Sulfated steroids as endogenous neuromodulators. Pharmacol Biochem Behav (2006) 84(4):555-67. doi: 10.1016/j.pbb.2006.07.031

17. Reddy DS. GABA-A receptors mediate tonic inhibition and neurosteroid sensitivity in the brain. Vitam Horm (2018) 107:177-91. doi: 10.1016/ bs.vh.2017.12.001

18. Reddy DS, Kulkarni SK. Proconvulsant effects of neurosteroids pregnenolone sulfate and dehydroepiandrosterone sulfate in mice. Eur J Pharmacol (1998) 345(1):55-9. doi: 10.1016/S0014-2999(98)00034-X

19. Maciejak P, Członkowska AI, Bidziński A, Walkowiak J, Szyndler J, Lehner $M$, et al. Pregnenolone sulfate potentiates the effects of NMDA on

\section{FUNDING}

This study received no external funding. The authors greatly acknowledge a statutory grant (DS 475/20) from Medical University of Lublin. Medical University of Lublin had no role in study design, data collection and analysis, decision to publish, or preparation of the manuscript.

hippocampal alanine and dopamine. Pharmacol Biochem Behav (2004) 78 (4):781-6. doi: 10.1016/j.pbb.2004.05.009

20. Maurice T, Phan VL, Urani A, Kamei H, Noda Y, Nabeshima T. Neuroactive neurosteroids as endogenous effectors for the sigmal (sigma1) receptor: pharmacological evidence and therapeutic opportunities. Jpn J Pharmacol (1999) 81(2):125-55. doi: 10.1254/jjp.81.125

21. Monnet FP, Mahé V, Robel P, Baulieu EE. Neurosteroids, via sigma receptors, modulate the $[3 \mathrm{H}]$ norepinephrine release evoked by N-methylD-aspartate in the rat hippocampus. Proc Natl Acad Sci U S A (1995) 92 (9):3774-8. doi: 10.1073/pnas.92.9.3774

22. Luoma JI, Stern CM, Mermelstein PG. Progesterone inhibition of neuronal calcium signaling underlies aspects of progesterone-mediated neuroprotection. J Steroid Biochem Mol Biol (2012) 131(1-2):30-6. doi: 10.1016/j.jsbmb.2011.11.002

23. Maguire J. Epileptogenesis: more than just the latent period. Epilepsy Curr (2016) 16(1):31-3. doi: 10.5698/1535-7597-16.1.31

24. Biagini G, Rustichelli C, Curia G, Vinet J, Lucchi C, Pugnaghi M, et al. Neurosteroids and epileptogenesis. J Neuroendocrinol (2013) 25(11):980-90. doi: $10.1111 /$ jne. 12063

25. Papadopoulos V, Baraldi M, Guilarte TR, Knudsen TB, Lacapère JJ, Lindemann $\mathrm{P}$, et al. Translocator protein $(18 \mathrm{kDa})$ : new nomenclature for the peripheraltype benzodiazepine receptor based on its structure and molecular function. Trends Pharmacol Sci (2006) 27(8):402-9. doi: 10.1016/j.tips.2006.06.005

26. Samba Reddy D, Ramanathan G. Finasteride inhibits the disease-modifying activity of progesterone in the hippocampus kindling model of epileptogenesis. Epilepsy Behav (2012) 25(1):92-7. doi: 10.1016/j.yebeh.2012.05.024

27. Selye H. The antagonism between anesthetic steroid hormones and pentamethylenetetrazol (Metrazol). J Lab Clin Med (1942) 27:3.

28. Mohammad S, Abolhassan A, Pourgholami MH. Evaluation of the anticonvulsant profile of progesterone in male amygdala-kindled rats Epilepsy Res (1998) 30:195-202. doi: 10.1016/S0920-1211(98)00004-7

29. Lonsdale D, Nylen K, McIntyre Burnham W. The anticonvulsant effects of progesterone and its metabolites on amygdala-kindled seizures in male rats. Brain Res (2006) 1101:110-6. doi: 10.1016/j.brainres.2006.05.005

30. Jeffrey M, Lang M, Gane J, Chow E, Wu C, Zhang L. Novel anticonvulsive effects of progesterone in a mouse model of hippocampal electrical kindling. Neuroscience (2014) 257:65-75. doi: 10.1016/j.neuroscience.2013.10.074

31. van Luijtelaar G, Budziszewska B, Jaworska-Feil L, Ellis J, Coenen A, Lasoń W. The ovarian hormones and absence epilepsy: a long-term EEG study and pharmacological effects in a genetic absence epilepsy model. Epilepsy Res (2001) 46:225-39. doi: 10.1016/s0920-1211(01)00277-7

32. Frye CA, Scalise TJ. Anti-seizure effects of progesterone and 3alpha, 5alphaTHP in kainic acid and perforant pathway models of epilepsy. Psychoneuroendocrinology (2000) 25:407-20. doi: 10.1016/s0306-4530(99) 00068-2

33. Billiar RB, Little B, Kline I, Reier P, Takaoka Y, White RJ. The metabolic clearance rate, head and brain extractions, and brain distribution and metabolism of progesterone in the anesthetized, female monkey (Macaca mulatta). Brain Res (1975) 94:99-113. doi: 10.1016/0006-8993(75)90880-x

34. Karavolas HJ, Hodges D, O'Brien D. Uptake of $(3 \mathrm{H})$ progesterone and $(3 \mathrm{H})$ 5 alphadihydroprogesterone by rat tissues in vivo and analysis of accumulated radioactivity: accumulation of 5alpha-dihydroprogesterone by pituitary and hypothalamic tissues. Endocrinology (1976) 98:164-75. doi: 10.1210/endo-98-1-164

35. Wu YV, Burnham WM. The anti-seizure effects of IV $5 \alpha$ dihydroprogesterone on amygdala-kindled seizures in rats. Epilepsy Res (2018) 146:132-6. doi: 10.1016/j.eplepsyres.2018.07.022 
36. Zorumski CF, Wittmer LL, Isenberg KE, Hu Y, Covey DF. Effects of neurosteroid and benz[e]indene enantiomers on GABAA receptors in cultured hippocampal neurons and transfected HEK-293 cells. Neuropharmacology (1996) 35(910):1161-8. doi: 10.1016/S0028-3908(96)00035-4

37. Akula KK, Dhir A, Kulkarni SK. Effect of various antiepileptic drugs in a pentylenetetrazol-induced seizure model in mice. Methods Find Exp Clin Pharmacol (2009) 31(7):423-32. doi: 10.1358/mf.2009.31.7.1415891

38. Meletti S, Lucchi C, Monti G, Giovannini G, Bedin R, Trenti T, et al. Low levels of progesterone and derivatives in cerebrospinal fluid of patients affected by status epilepticus. J Neurochem (2018) 147(2):275-84. doi: $10.1111 /$ jnc. 14550

39. Mòdol L, Darbra S, Vallèe $M$, Pallarès $M$. Alteration of neonatal allopregnanolone levels affects exploration, anxiety, aversive learning and adult behavioural response to intrahippocampal neurosteroids. Behav Brain Res (2013) 241:96-104. doi: 10.1016/j.bbr.2012.11.043

40. Noorbakhsh F, Ellestad KK, Maingat F, Warren KG, Han MH, Steinman L, et al. Impaired neurosteroid synthesis in multiple sclerosis. Brain (2011) 134 (Pt 9):2703-21. doi: 10.1093/brain/awr200

41. Djebaili M, Guo Q, Pettus EH, Hoffman SW, Stein DG. The neurosteroids progesterone and allopregnanolone reduce cell death, gliosis, and functional deficits after traumatic brain injury in rats. J Neurotrauma (2005) 22(1):10618. doi: 10.1089/neu.2005.22.106

42. Wojtal K, Trojnar MK, Czuczwar SJ. Endogenous neuroprotective factors: neurosteroids. Pharmacol Rep (2006) 58(3):335-40.

43. Kaciński M, Leśkiewicz M, Jaworska-Feil L, Zajac A, Kubik A, Budziszewska B, et al. Pseudo-epileptic seizures in children are not associated with enhanced plasma level of allopregnanolone. Pharmacol Rep (2007) 59 (6):683-90.

44. Lévesque M, Herrington R, Leclerc L, Rogawski MA, Avoli M. Allopregnanolone decreases interictal spiking and fast ripples in an animal model of mesial temporal lobe epilepsy. Neuropharmacology (2017) 121:12-9. doi: 10.1016/j.neuropharm.2017.04.020

45. Rogawski MA, Loya CM, Reddy K, Zolkowska D, Lossin C. Neuroactive steroids for the treatment of status epilepticus. Epilepsia (2013) 54 Suppl 6:93-8. doi: 10.1111/epi.12289

46. Lucchi C, Costa AM, Rustichelli C, Biagini G. Allopregnanolone and pregnanolone are reduced in the hippocampus of epileptic rats, but only allopregnanolone correlates with the seizure frequency. Neuroendocrinology (2020). doi: $10.1159 / 000509093$

47. Meletti S, Lucchi C, Monti G, Giovannini G, Bedin R, Trenti T, et al. Decreased allopregnanolone levels in cerebrospinal fluid obtained during status epilepticus. Epilepsia (2017) 58(2):e16-20. doi: 10.1111/epi.13625

48. Vaitkevicius H, Husain AM, Rosenthal ES, Rosand J, Bobb W, Reddy K, et al. First-in-man allopregnanolone use in super-refractory status epilepticus. Ann Clin Transl Neurol (2017) 4(6):411-14. doi: 10.1002/acn3.408

49. Rogawski MA, Reddy DS. Neurosteroids and infantile spasms: the deoxycorticosterone hypothesis. Int Rev Neurobiol (2002) 49:199-219. doi: 10.1016/S0074-7742(02)49014-9

50. Banerjee PK, Snead OC3. Neuroactive steroids exacerbate gammahydroxybutyric acid-induced absence in rats. Eur J Pharmacol (1998) 359 (1):41-8. doi: 10.1016/S0014-2999(98)00629-3

51. Nohria V, Giller E. Ganaxolone. Neurotherapeutics (2007) 4(1):102-5. doi: 10.1016/j.nurt.2006.11.003

52. Carver CM, Reddy DS. Neurosteroid interactions with synaptic and extrasynaptic $\mathrm{GABA}(\mathrm{A})$ receptors: regulation of subunit plasticity, phasic and tonic inhibition, and neuronal network excitability. Psychopharmacol (Berl) (2013) 230(2):151-88. doi: 10.1007/s00213-013-3276-5

53. Zaccara G, Schmidt D. Do traditional anti-seizure drugs have a future? A review of potential antiseizure drugs in clinical development. Pharmacol Res (2016) 104:38-48. doi: 10.1016/j.phrs.2015.12.011

54. Reddy DS, Woodward R. Ganaxolone: a prospective overview. Drugs Future (2004) 29:227-42. doi: 10.1358/dof.2004.029.03.793135

55. Gasior M, Ungard JT, Beekman M, Carter RB, Witkin JM. Acute and chronic effects of the synthetic neuroactive steroid, ganaxolone, against the convulsive and lethal effects of pentylenetetrazol in seizure-kindled mice: comparison with diazepam and valproate. Neuropharmacology (2000) 39 (7):1184-96. doi: 10.1016/s0028-3908(99)00190-2
56. Reddy DS, Rogawski MA. Ganaxolone suppression of behavioral and electrographic seizures in the mouse amygdala kindling model. Epilepsy Res (2010) 89(2-3):254-60. doi: 10.1016/j.eplepsyres.2010.01.009

57. Mares P, Stehlíková M. Anticonvulsant doses of ganaxolone do not compromise motor performance in immature rats. Neurosci Lett (2010) 469(3):396-9. doi: 10.1016/j.neulet.2009.12.037

58. Citraro R, Russo E, Di Paola ED, Ibbadu GF, Gratteri S, Marra R, et al. Effects of some neurosteroids injected into some brain areas of WAG/Rij rats, an animal model of generalized absence epilepsy. Neuropharmacology (2006) 50 (8):1059-71. doi: 10.1016/j.neuropharm.2006.02.011

59. Bialer M, Johannessen SI, Levy RH, Perucca E, Tomson T, White HS Progress report on new antiepileptic drugs: a summary of the Tenth Eilat Conference (EILAT X). Epilepsy Res (2010) 92(2-3):89-124. doi: 10.1016/ j.eplepsyres.2010.09.001

60. Bialer M, Johannessen SI, Levy RH, Perucca E, Tomson T, White HS Progress report on new antiepileptic drugs: a summary of the Eleventh Eilat Conference (EILAT XI). Epilepsy Res (2013) 103(1):2-30. doi: 10.1016/ j.eplepsyres.2012.10.001

61. Sperling MR, Klein P, Tsai J. Randomized, double-blind, placebo-controlled phase 2 study of ganaxolone as add-on therapy in adults with uncontrolled partial-onset seizures. Epilepsia (2017) 58(4):558-64. doi: 10.1111/epi.13705

62. Weir CJ, Ling AT, Belelli D, Wildsmith JA, Peters JA, Lambert JJ. The interaction of anaesthetic steroids with recombinant glycine and GABAA receptors. Br J Anaesth (2004) 92(5):704-11. doi: 10.1093/bja/aeh125

63. Rogawski MA, Reddy DS. Neurosteroids: endogenous modulators of seizures susceptibility: in Epilepsy: Scientific Foundations of Clinical Practive. JM Rho, R Sankar and J Cavazos, editors. New York: Marcel Dekker (2004) p. 319-55.

64. Budziszewska B, Siwanowicz J, Leśkiewicz M, Jaworska-Feil L, Lasoń W. Protective effects of neurosteroids against NMDA-induced seizures and lethality in mice. Eur J Neuropsychopharmacol (1998) 8(1):7-12. doi: 10.1016/S0924-977X(97)00037-0

65. Borowicz KK, Zadrozniak M, Swiader M, Kowalska A, Kleinrok Z, Czuczwar SJ. Interaction of the neurosteroid alphaxalone with conventional antiepileptic drugs in different types of experimental seizures. Eur J Pharmacol (2002) 449(1-2):85-90. doi: 10.1016/S0014-2999(02)01975-1

66. Chuang SH, Reddy DS. Isobolographic analysis of antiseizure activity of the GABA-A receptor-modulating synthetic neurosteroids brexanolone and ganaxolone with tiagabine and midazolam. J Pharmacol Exp Ther (2020) 372(3):285-98. doi: 10.1124/jpet.119.261735

67. Zolkowska D, Wu CY, Rogawski MA. Intramuscular allopregnanolone and ganaxolone in a mouse model of treatment-resistant status epilepticus. Epilepsia (2018) 59 Suppl 2:220-7. doi: 10.1111/epi.13999

68. Joshi S, Kapur J. Neurosteroid regulation of GABAA receptors: A role in catamenial epilepsy. Brain Res (2019) 1703:31-40. doi: 10.1016/ j.brainres.2018.02.031

69. Herzog AG. Catamenial epilepsy: Update on prevalence, pathophysiology and treatment from the findings of the NIH Progesterone Treatment Trial. Seizure (2015) 28:18-25. doi: 10.1016/j.seizure.2015.02.024

70. Maguire MJ, Nevitt SJ. Treatments for seizures in catamenial (menstrualrelated) epilepsy. Cochrane Database Syst Rev (2019) 10:CD013225. doi: 10.1002/14651858.CD013225

71. Maguire JL, Stell BM, Rafizadeh M, Mody I. Ovarian cycle-linked changes in GABA(A) receptors mediating tonic inhibition alter seizure susceptibility and anxiety. Nat Neurosci (2005) 8(6):797-804. doi: 10.1038/nn1469

72. Reddy DS. Neurosteroids and their role in sex-specific epilepsies. Neurobiol Dis (2014) 72 PB:198-209. doi: 10.1016/j.nbd.2014.06.010

73. Wu YV, Burnham WM. Progesterone, 5a-dihydropogesterone and allopregnanolone's effects on seizures: A review of animal and clinical studies. Seizure (2018) 63:26-36. doi: 10.1016/j.seizure.2018.10.012

74. Dana-Haeri J, Richens A. Effect of norethisterone on seizures associated with menstruation. Epilepsia (1983) 24(3):377-81. doi: 10.1111/j.15281157.1983.tb04901.x

75. Herzog AG, Frye CA. Seizure exacerbation associated with inhibition of progesterone metabolism. Ann Neurol (2003) 53(3):390-1. doi: 10.1002/ ana. 10508

76. Herzog AG, Fowler KM, Smithson SD, Kalayjian LA, Heck CN, Sperling MR, et al. Progesterone vs placebo therapy for women with epilepsy: A 
randomized clinical trial. Neurology (2012) 78(24):1959-66. doi: 10.1212/ WNL.0b013e318259elf9

77. Herzog AG, Frye CAProgesterone Trial Study Group. Allopregnanolone levels and seizure frequency in progesterone-treated women with epilepsy. Neurology (2014) 83(4):345-8. doi: 10.1212/WNL.0000000000000623

78. Motta E, Golba A, Ostrowska Z, Steposz A, Huc M, Kotas-Rusnak J, et al. Progesterone therapy in women with epilepsy. Pharmacol Rep (2013) 65 (1):89-98. doi: 10.1016/s1734-1140(13)70967-8

79. Mostacci B, Esposto R, Lello S, Bisulli F, Licchetta L, Tinuper P. Estrogenrelated seizure exacerbation following hormone therapy for assisted reproduction in women with epilepsy. Seizure (2018) 61:200-2. doi: 10.1016/j.seizure.2018.08.024

80. Woolley CS, McEwen BS. Estradiol regulates hippocampal dendritic spine density via an N-methyl-D-aspartate receptor-dependent mechanism. $J$ Neurosci (1994) 14(12):7680-7. doi: 10.1523/JNEUROSCI.14-1207680.1994

81. Smejkalova T, Woolley CS. Estradiol acutely potentiates hippocampal excitatory synaptic transmission through a presynaptic mechanism. J Neurosci (2010) 30(48):16137-48. doi: 10.1523/JNEUROSCI.4161-10.2010

82. Pottoo FH, Javed MN, Barkat MA, Alam MS, Nowshehri JA, Alshayban DM, et al. Estrogen and serotonin: Complexity of interactions and implications for epileptic seizures and epileptogenesis. Curr Neuropharmacol (2019) 17(3):21431. doi: 10.2174/1570159X16666180628164432

83. McEwen BS. Invited review: Estrogens effects on the brain: multiple sites and molecular mechanisms. J Appl Physiol (2001) 91(6):2785-801. doi: 10.1152/ jappl.2001.91.6.2785

84. Iqbal R, Jain GK, Siraj F, Vohora D. Aromatase inhibition by letrozole attenuates kainic acid-induced seizures but not neurotoxicity in mice. Epilepsy Res (2018) 143:60-9. doi: 10.1016/j.eplepsyres.2018.04.004

85. Rashid D, Panda BP, Vohora D. Reduced estradiol synthesis by letrozole, an aromatase inhibitor, is protective against development of pentylenetetrazoleinduced kindling in mice. Neurochem Int (2015) 90:271-4. doi: 10.1016/ j.neuint.2015.10.001

86. Tutka P, Mróz K, Mróz T, Buszewicz G, Aebisher D, Bartusik-Aebisher D, et al. Effects of androsterone on the protective action of various antiepileptic drugs against maximal electroshock-induced seizures in mice. Psychoneuroendocrinology (2019) 101:27-34. doi: 10.1016/j.psyneuen.2018.10.017

87. Edwards HE, Vimal S, Burnham WM. Dose-, time-, age, and sex-response profiles for the anticonvulsant effects of deoxycorticosterone in 15-day-oldrats. Exp Neurol (2002) 176(2):364-70. doi: 10.1006/exnr.2002.7931

88. Perez-Cruz C, Lonsdale D, Burnham WM. Anticonvulsant actions of deoxycorticosterone. Brain Res (2007) 1145:81-9. doi: 10.1016/ j.brainres.2007.01.123

89. Pawluski JL, Kuchenbuch M, Hadjadj S, Dieuset G, Costet N, Vercueil L, et al. Long-term negative impact of an inappropriate first antiepileptic medication on the efficacy of a second antiepileptic medication in mice. Epilepsia (2018) 59(7):e109-e13. doi: 10.1111/epi.14454

90. Löscher W, Puskarjov M, Kaila K. Cation-chloride cotransporters NKCC1 and KCC2 as potential targets for novel antiepileptic and antiepileptogenic treatments. Neuropharmacology (2013) 69:62-74. doi: 10.1016/j.neuropharm.2012.05.045

91. Flossmann T, Kaas T, Rahmati V, Kiebel SJ, Witte OW, Holthoff K, et al. Somatostatin interneurons promote neuronal synchrony in the neonatal hippocampus. Cell Rep (2019) 26(12):3173-82. doi: 10.1016/j.celrep.2019.02.061

92. Valeeva G, Tressard T, Mukhtarov M, Baude A, Khazipov R. An optogenetic approach for investigation of excitatory and inhibitory network GABA actions in mice expressing channelrhodopsin-2 in GABAergic neurons. $J$ Neurosci (2016) 36(22):5961-73. doi: 10.1523/JNEUROSCI.3482-15.2016

93. Ben-Ari Y, Khalilov I, Kahle KT, Cherubini E. The GABA excitatory/ inhibitory shift in brain maturation and neurological disorders. Neuroscientist (2012) 18(5):467-86. doi: 10.1177/1073858412438697

94. Plotkin MD, Snyder EY, Hebert SC, Delpire E. Expression of the Na-K-2Cl cotransporter is developmentally regulated in postnatal rat brains: a possible mechanism underlying GABA's excitatory role in immature brain. J Neurobiol (1997) 33(6):781-95. doi: 10.1002/(SICI)1097-4695(19971120) 33:6<781::AID-NEU6>3.0.CO;2-5

95. Dzhala VI, Talos DM, Sdrulla DA, Brumback AC, Mathews GC, Benke TA, et al. NKCC1 transporter facilitates seizures in the developing brain. Nat Med (2005) 11(11):1205-13. doi: 10.1038/nm1301
96. Tyzio R, Holmes GL, Ben-Ari Y, Khazipov R. Timing of the developmental switch in $\mathrm{GABA}(\mathrm{A})$ mediated signaling from excitation to inhibition in CA3 rat hippocampus using gramicidin perforated patch and extracellular recordings. Epilepsia (2007) 48 Suppl 5:96-105. doi: 10.1111/j.15281167.2007.01295.x

97. Kolbaev SN, Sharopov S, Dierkes PW, Luhmann HJ, Kilb W. Phasic GABAA-receptor activation is required to suppress epileptiform activity in the CA3 region of the immature rat hippocampus. Epilepsia (2012) 53 (5):888-96. doi: 10.1111/j.1528-1167.2012.03442.x

98. Spigelman I, Li Z, Liang J, Cagetti E, Samzadeh S, Mihalek RM, et al. Reduced inhibition and sensitivity to neurosteroids in hippocampus of mice lacking the GABA(A) receptor delta subunit. J Neurophysiol (2003) 90 (2):903-10. doi: 10.1152/jn.01022.2002

99. Sharopov S, Winkler P, Uehara R, Lombardi A, Halbhuber L, Okabe A, et al. Allopregnanolone augments epileptiform activity of an in-vitro mouse hippocampal preparation in the first postnatal week. Epilepsy Res (2019) 157:106196. doi: 10.1016/j.eplepsyres.2019.106196

100. Mares P. Anticonvulsant action of three neurosteroids against cortical epileptic afterdischarges in immature rats. Brain Res Bull (2005) 68 (3):179-84. doi: 10.1016/j.brainresbull.2005.08.008

101. Mares P, Mikulecká A, Haugvicová R, Kasal A. Anticonvulsant action of allopregnanolone in immature rats. Epilepsy Res (2006) 70(2-3):110-7. doi: 10.1016/j.eplepsyres.2006.03.009

102. Mares P, Kubová H, Kasal A. Anticonvulsant action of a new analogue of allopregnanolone in immature rats. Physiol Res (2010) 59(2):305-8.

103. Clancy B, Finlay BL, Darlington RB, Anand KJ. Extrapolating brain development from experimental species to humans. Neurotoxicology (2007) 28(5):931-7. doi: 10.1016/j.neuro.2007.01.014

104. Hirst JJ, Cumberland AL, Shaw JC, Bennett GA, Kelleher MA, Walker DW, et al. Loss of neurosteroid-mediated protection following stress during fetal life. J Steroid Biochem Mol Biol (2016) 160:181-8. doi: 10.1016/j.jsbmb.2015.09.012

105. Perez-Cruz C, Likhodii S, Burnham WM. Deoxycorticosterone,s anticonvulsant effects in infant rats are blocked by finasteride, but not by indomethacin. Exp Neurol (2006) 200(2):283-9. doi: 10.1016/ j.expneurol.2006.02.012

106. Broomall E, Natale JE, Grimason M, Goldstein J, Smith CM, Chang C, et al. Pediatric super-refractory status epilepticus treated with allopregnanolone. Ann Neurol (2014) 76(6):911-5. doi: 10.1002/ana.24295

107. Grosso S, Luisi S, Mostardini R, Farnetani M, Cobellis L, Morgese G, et al. Inter-ictal and post-ictal circulating levels of allopregnanolone, an anticonvulsant metabolite of progesterone, in epileptic children. Epilepsy Res (2003) 54(1):29-34. doi: 10.1016/S0920-1211(03)00042-1

108. Tan C, Shard C, Ranieri E, Hynes K, Pham DH, Leach D, et al. Mutations of protocadherin 19 in female epilepsy (PCDH19-FE) lead to allopregnanolone deficiency. J Hum Mol Genet (2015) 24(18):5250-9. doi: 10.1093/hmg/ ddv 245

109. Trivisano M, Lucchi C, Rustichelli C, Terracciano A, Cusmai R, Ubertini GM, et al. Reduced steroidogenesis in patients with PCDH19-female limited epilepsy. Epilepsia (2017) 58(6):e91-5. doi: 10.1111/epi.13772

110. Kerrigan JF, Shields WD, Nelson TY, Bluestone DL, Dodson WE, Bourgeois $\mathrm{BF}$, et al. Ganaxolone for treating intractable infantile spasms: a multicenter, open-label, add-on trial. Epilepsy Res (2000) 42(2-3):133-9. doi: 10.1016/ S0920-1211(00)00170-4

111. Pieribone VA, Tsai J, Soufflet C, Rey E, Shaw K, Giller E, et al. Clinical evaluation of ganaxolone in pediatric and adolescent patients with refractory epilepsy. Epilepsia (2007) 48(10):1870-4. doi: 10.1111/j.1528-1167.2007.01182.x

112. Yawno T, Miller SL, Bennet L, Wong F, Hirst JJ, Fahey M, et al. Ganaxolone: a new treatment for neonatal seizures. Front Cell Neurosci (2017) 11:246:246. doi: 10.3389/fncel.2017.00246

113. Borowicz KK, Wilczyński PM, Kleinrok Z, Czuczwar SJ. Rimcazole, a sigma receptor ligand, and the anticonvulsive action of conventional antiepileptic drugs. J Neural Transm (1998) 105(6-7):601-12. doi: 10.1007/s007020050082

114. Kułak W, Sobaniec W, Wojtal K, Czuczwar SJ. Calcium modulation in epilepsy. Pol J Pharmacol (2004) 56(1):29-41.

115. Pisu MG, Mostallino MC, Dore R, Mura ML, Maciocco E, Russo E, et al. Neuroactive steroids and GABAA receptor plasticity in the brain of the WAG/Rij rat, a model of absence epilepsy. J Neurochem (2008) 106(6):250214. doi: 10.1111/j.1471-4159.2008.05538.x 
116. Perry MS. New and emerging medications for treatment of pediatric epilepsy. Pediatr Neurol (2019) 107:24-7. doi: 10.1016/j.pediatrneurol. 2019.11.008

117. Olney JW, Young C, Wozniak DF, Jevtovic-Todorovic V, Ikonomidou C. Do pediatric drugs cause developing neurons to commit suicide? Trends Pharmacol Sci (2004) 25(3):135-9. doi: 10.1016/j.tips.2004.01.002

Conflict of Interest: SC was granted financial support from Bayer, GlaxoSmithKline, Janssen, Novartis, Sanofi-Aventis for lecturing (until 2014). $\mathrm{He}$ also received an unrestricted grant from GlaxoSmithKline for the period of 2006-2007.
The remaining authors declare that the research was conducted in the absence of any commercial or financial relationships that could be construed as a potential conflict of interest.

Copyright (c) 2020 Miziak, Chrościńska-Krawczyk and Czuczwar. This is an openaccess article distributed under the terms of the Creative Commons Attribution License (CC BY). The use, distribution or reproduction in other forums is permitted, provided the original author(s) and the copyright owner(s) are credited and that the original publication in this journal is cited, in accordance with accepted academic practice. No use, distribution or reproduction is permitted which does not comply with these terms. 